\title{
Librarians and Faculty Members: Coping with Pressures to Publish
}

\section{Robert Boice, Jordan M. Scepanski, and Wayne Wilson}

Matched groups of librarians and faculty members demonstrated similar styles of coping with new pressures for scholarly writing. While external observations and self-reports of librarians confirmed that they had longer workweeks (on campus) than did faculty, both groups evidenced sufficient time for scholarship amid busy schedules. Moreover, neither group took advantage of directives for using available time for writing. These librarians and faculty claimed to be too busy to publish but other constraints such as insecurities, entrenched work habits, and unsupportive workplace cultures appeared to be the most significant factors accounting for their failure to pursue scholarly writing projects.

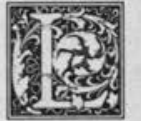

ibrarians' struggles with faculty status bring to mind an old maxim: happiness isn't so much getting what you want as wanting what you get. Many academic librarians who have achieved that status show an uneasiness with their prize.

Elevation to faculty status has heightened the role conflict librarians experience between their commitment to library users and to scholarship, and from the pressures to publish. ${ }^{1}$ Moreover, librarians who value their status as faculty members wonder about the fairness of being compared to traditional faculty whose schedules seemingly permit more time for scholarship. ${ }^{2}$

The literature of academic librarianship abounds with articles expressing ambivalence about faculty status. ${ }^{3}$ However, librarians have failed to establish, in any verifiable way, that they face unique pressures and problems resulting from the conflict between the demands of faculty status and the provision of public service. Until they document their problems, librarians may be doomed to an unresolved ambivalence.

The lack of comparable literature about traditional faculty may account in part for the scarcity of solutions. Consider, for example, that the majority of faculty work on campuses where pressures to publish are new, unexpected, and generally unwelcomed. ${ }^{4}$ These faculty, like librarians, worry about a decline in morale and assume that research and scholarship can grow only at the expense of service to students. ${ }^{5,6}$

Examining this parallel literature can offer, in addition to the opportunity to commiserate over similar problems, solutions

Robert Boice is Director of the Center for Faculty Development and Professor of Psychology, and Jordan M. Scepanski is Director, University Library and Learning Resources at California State University, Long Beach, California 90840. Wayne Wilson is Library Director at Chapman College, Orange, California 92666. 
to the most serious concern: how to combine service or teaching with scholarship.

One such study began with a reexamination of traditional assertions about teaching and scholarship. First, it became apparent that long-standing negativism among faculty members about their ability to perform both activities well was based on questionable evidence. The few empirical investigations show either no relationship between teaching and research or only a slight indication that the best teachers tend to be researchers. ' Second, it became apparent that conclusions about the connection between teaching and scholarship should be based on direct tests. Studies were reexamined that reported cases in which faculty were directly rewarded to improve in both categories. In such a context, teaching and scholarship became mutually facilitative. ${ }^{8}$ In other words, widespread beliefs that excellence must be confined to either teaching or research were shown to be questionable.

\section{"... widespread beliefs that excel- lence must be confined to either teaching or research were shown to be questionable."}

Another popular view is that most professors, especially those with heavy teaching loads, are too busy for scholarship. Proof for this claim typically rests on selfreports by faculty that they work fifty to sixty hours a week. ${ }^{9}$ Here again, reexamination of claims brought a new perspective: while faculty may actually believe their estimates of length of workweek, their self-reports are often exaggerated. ${ }^{10}$ Where workweeks have been observed directly, their length has been much shorter. ${ }^{11}$

Longitudinal studies of faculty members help explain why they overestimate their workloads and underestimate their capacity for scholarship. Many faculty do not manage their time well. Some, also, do not know when they have fulfilled certain obligations and, as a result, spend more time than is necessary on these activities. Moreover, faculty maintain views about scholarship that undermine realistic attempts at writing for publication. They often believe, for example, that effective writing requires large, uninterrupted blocks of time. In fact, it has been shown faculty tend to be more productive when they write in daily sessions of thirty to forty-five minutes. ${ }^{12}$

The present study is an initial attempt to reexamine librarians' concerns about faculty status as they relate to publishing. It addresses the questions of how librarians spend their time, if they have time for scholarship, and if scholarship can be accomplished without undermining service to library clientele. To provide preliminary answers to these questions, this study adopted an economical but direct method for observing and analyzing how librarians spend their time.

The focus of this study is unusual in research on librarians. It assumes that librarians and faculty resemble each other more than either group realizes, and it examines the possibility that librarians, like the faculty at large, do have sufficient time and background to meet the demands of scholarship.

\section{METHODS}

\section{Subjects}

The twelve librarians depicted here have full faculty status at a large university. Their salary schedule is identical to the teaching faculty. They have ranks equivalent to the professoriat and are eligible for tenure and sabbaticals. They also have representation in the university's senate, councils, and committees on the same basis as the teaching faculty. As members of the union that represents the faculty at large, librarians are by a negotiated agreement expected to work "an average of forty (40) hours in a seven (7) day period." The twelve subjects are all tenured. They represent each of the four academic ranks, and, with one exception, work in public service areas. The subjects have little or no supervisory responsibilities. Each volunteered to be visited on a "spot observational schedule" by one of 
the authors and to maintain daily records of their work activities for a period of at least one year.

The comparison group of twelve faculty members came from two large universities, four of them from the same campus as the librarians studied. This sample of faculty members was selected according to a larger collection of observations on the basis of gender (four males are in the librarians group) and years in service (all have ten or more years of work experience). All the faculty members in the sample came from campuses where pressures for scholarship, research, and publishing were seen as relatively new.

\section{Enlisting Participants}

Getting faculty members or librarians to agree to weekly visits by an observer is not necessarily difficult. Recruitment was aided by the support of administrators. ${ }^{13}$ The dean or the library director agreed to invite the observer to speak about the nature and aims of the project and also underscored the potential value of the project, as well as working behind the scenes to coax (but not coerce) individuals to volunteer.

The aims and goals presented to participants during the meetings arranged by administrators can be abstracted as (1) descriptions of the self-report sheets and of the observer's visits; (2) clear assurances that information about individuals would remain confidential and that reports of findings would assure anonymity; (3) explanations of why documenting how time spent and how one handles pressures for scholarship is important in helping librarians and faculty to flourish (and in educating higher administrators about changes and supports necessary for overall productivity); and (4) answering questions, especially from those concerned that scholarly demands would pressure them to abandon good service.

\section{Self-Report Forms}

Table 1 shows the basic format of the self-report sheets that both groups completed each week; faculty and librarians indicated with arrows on each sheet the length of time spent on particular activities. Activities were coded from the categories listed at the top of the sheet. Ratings of intensity and enjoyment indicated participants' estimates of how hard they felt they were working and how positively they felt about what they were doing at the time $(1=$ no intensity or no enjoyment, and $10=$ maximal intensity or enjoyment).

The observer, in weekly, unannounced visits to participants, provided an important check on the objectivity of the selfreports. At this time the observer typically checked off (1) his own classification and rating of the ongoing activity and (2) whether or not the participant was maintaining the self-report form. Most participants reported that maintaining verified self-reports on a daily basis led to very different accounts of workweeks than they had previously thought or reported in other surveys.

\section{Tracking Participants}

Except for a few instances when either participants or the observer were away from campus, all twenty-four individuals were observed weekly over a sevenmonth period, which began prior to and ended after the spring semester. Potential times for visits were arrived at by reviewing self-report forms that indicated regularly scheduled activities, information solicited about future plans, and administratively issued schedules. Each weekly visit lasted between ten and twenty minutes.

Where practical, tracking visits were planned to sample the typical range of oncampus activities of each participant. In visits where participants were actively working with students, (e.g., classroom lecturing or with library users, e.g., conducting an online search), the observer remained unobtrusive. During visits where participants had lulls in activity, the observer encouraged them to talk about their work. On occasional preplanned visits, all members of a sample group were asked a standard "question of the week" (e.g., describe the most satisfying event that occurred recently in your professional work. 
TABLE 1

\section{SAMPLE SELF-REPORT SHEET FILLED OUT WEEKLY BY LIBRARIANS}

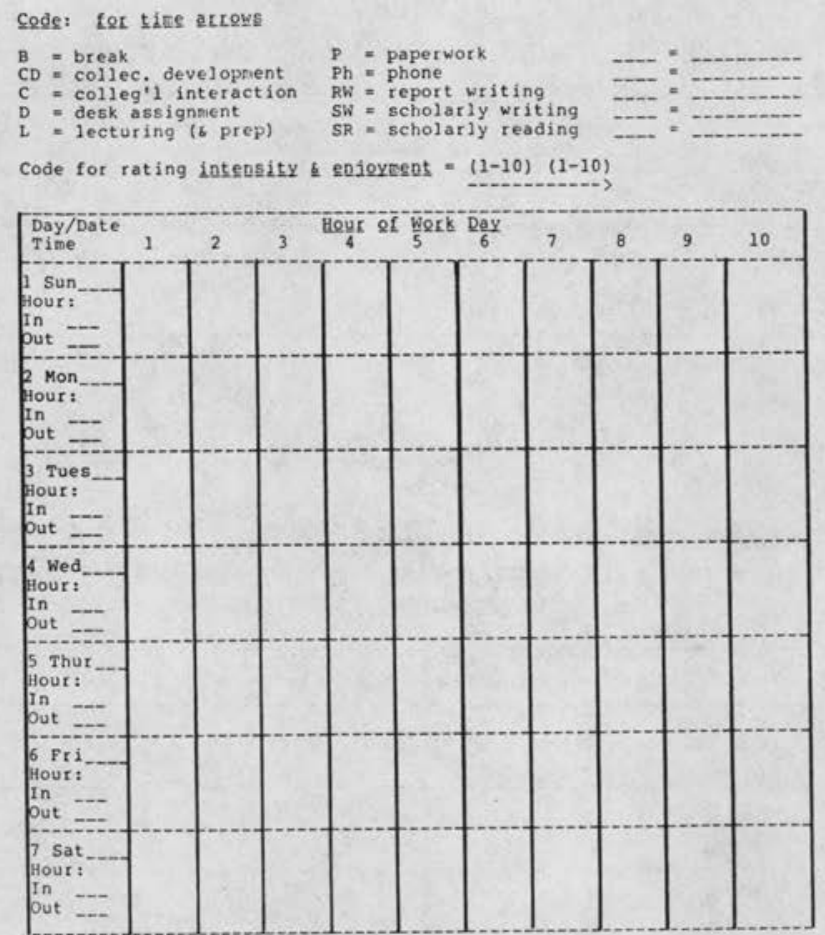

\section{RESULTS}

\section{Practicality and Reliability of the Methodology}

Table 2 shows that weekly observations were regular for both sample groups. Each week the observer typically spent 4.5 hours with librarians and 6 hours with faculty. The difference was due mainly to the fact that librarians are located in one building while faculty are not. An important point to be drawn from table 2 is that both groups were accessible and cooperative.

Except in rating the subjective aspects of ongoing activities, judgments by faculty and the observer about the kinds of activities and when they were carried out were in close agreement. This result supports the contention that direct observational checks can validate the reliability of faculty's self-reports of workweeks.

Table 3 presents the judgments of librar- ians and the observer on the intensity and enjoyment levels of ongoing activities. In general, this aspect of reliability, i.e., the coincidence of agreement between the observer's and the faculty member's judgment on the level of intensity/enjoyment, was mediocre. Table 3 shows, however, some of the potential in comparing the ratings of work intensity/enjoyment made by a trained observer with ratings made by the individuals themselves. Some librarians, usually those who describe themselves as chronically rushed and busy, rated themselves unrealistically high on the intensity dimension. Other librarians, usually those who seemed to be burned out under stress, consistently ranked themselves low in terms of enjoyment evidenced during activities. Even though the sample is too small for firm conclusions, another result merits mention. Librarians whose judgments about intensity and en- 
TABLE 2

SAMPLES OF ACCESS AND COMPLIANCE LEVELS

\begin{tabular}{|c|c|c|c|c|c|c|c|c|c|}
\hline \multirow[b]{2}{*}{ Week } & \multicolumn{9}{|c|}{$\begin{array}{l}\text { Number of Participants } \\
\text { Access (by Observer) or Self-Report (Completion of Sheets) }\end{array}$} \\
\hline & 2 & 4 & 8 & 12 & 16 & 20 & 24 & 28 & 30 \\
\hline $\begin{array}{l}\text { Access } \\
\text { Librarians }\end{array}$ & 6 & 7 & 9 & 12 & 11 & 10 & 12 & 12 & 12 \\
\hline Self-report & 6 & 9 & 10 & 11 & 10 & 11 & 11 & 11 & 11 \\
\hline $\begin{array}{l}\text { Access } \\
\text { Faculty Members }\end{array}$ & 10 & 12 & 10 & 11 & 12 & 12 & 11 & 12 & 11 \\
\hline Self-report & 10 & 12 & 10 & 11 & 11 & 12 & 10 & 10 & 10 \\
\hline
\end{tabular}

TABLE 3

SAMPLES OF LIBRARIANS' SELF-RATINGS AND OBSERVERS' RATINGS DURING WEEKLY VISITS*

\begin{tabular}{|c|c|c|c|c|c|c|c|c|c|c|}
\hline \multirow[b]{2}{*}{$\begin{array}{l}\text { Libr. A } \\
\text { Obs. }\end{array}$} & \multicolumn{10}{|c|}{ Successive Weekly Ratings of Energy Expended (10 = maximum) } \\
\hline & $\begin{array}{r}10 \\
3\end{array}$ & $\begin{array}{l}8 \\
6\end{array}$ & $\begin{array}{l}6 \\
3\end{array}$ & $\begin{array}{l}9 \\
3\end{array}$ & $\begin{array}{r}10 \\
9\end{array}$ & $\begin{array}{l}5 \\
5\end{array}$ & $\begin{array}{l}7 \\
8\end{array}$ & $\begin{array}{l}2 \\
3\end{array}$ & $\begin{array}{l}2 \\
8\end{array}$ & $\begin{array}{l}4 \\
4\end{array}$ \\
\hline $\begin{array}{l}\text { Libr. B } \\
\text { Obs. }\end{array}$ & $\begin{array}{l}9 \\
6\end{array}$ & $\begin{array}{l}8 \\
4\end{array}$ & $\begin{array}{r}10 \\
4\end{array}$ & $\begin{array}{l}8 \\
4\end{array}$ & $\begin{array}{l}7 \\
6\end{array}$ & $\begin{array}{l}4 \\
4\end{array}$ & $\begin{array}{l}9 \\
6\end{array}$ & $\begin{array}{l}8 \\
8\end{array}$ & $\begin{array}{l}8 \\
6\end{array}$ & $\begin{array}{l}6 \\
4\end{array}$ \\
\hline $\begin{array}{l}\text { Libr. C } \\
\text { Obs. }\end{array}$ & $\begin{array}{l}6 \\
6\end{array}$ & $\begin{array}{l}4 \\
4\end{array}$ & $\begin{array}{l}9 \\
4\end{array}$ & $\begin{array}{l}7 \\
2\end{array}$ & $\begin{array}{l}3 \\
6\end{array}$ & $\begin{array}{l}5 \\
2\end{array}$ & $\begin{array}{l}4 \\
3\end{array}$ & $\begin{array}{l}4 \\
3\end{array}$ & $\begin{array}{l}4 \\
4\end{array}$ & $\begin{array}{l}4 \\
4\end{array}$ \\
\hline $\begin{array}{l}\text { Libr. D } \\
\text { Obs. }\end{array}$ & $\begin{array}{r}10 \\
2\end{array}$ & $\begin{array}{l}9 \\
2\end{array}$ & $\begin{array}{r}10 \\
2\end{array}$ & $\begin{array}{l}9 \\
3\end{array}$ & $\begin{array}{l}6 \\
5\end{array}$ & $\begin{array}{l}9 \\
5\end{array}$ & $\begin{array}{l}9 \\
5\end{array}$ & $\begin{array}{l}8 \\
3\end{array}$ & $\begin{array}{l}7 \\
2\end{array}$ & $\begin{array}{r}10 \\
2\end{array}$ \\
\hline \multirow[t]{2}{*}{$\begin{array}{l}\text { Libr. E } \\
\text { Obs. }\end{array}$} & $\begin{array}{l}4 \\
1\end{array}$ & $\begin{array}{l}4 \\
5\end{array}$ & $\begin{array}{l}5 \\
7\end{array}$ & $\begin{array}{l}5 \\
8\end{array}$ & $\begin{array}{l}7 \\
6\end{array}$ & $\begin{array}{l}5 \\
6\end{array}$ & $\begin{array}{l}9 \\
8\end{array}$ & $\begin{array}{l}9 \\
8\end{array}$ & $\begin{array}{l}5 \\
8\end{array}$ & $\begin{array}{l}8 \\
7\end{array}$ \\
\hline & \multicolumn{10}{|c|}{ Successive Weekly Ratings of Enjoyment Evidenced ( $10=$ maximum $)$} \\
\hline $\begin{array}{l}\text { Libr. A } \\
\text { Obs. }\end{array}$ & $\begin{array}{r}10 \\
5 \\
\end{array}$ & $\begin{array}{l}6 \\
6 \\
\end{array}$ & $\begin{array}{l}6 \\
8 \\
\end{array}$ & $\begin{array}{l}3 \\
5 \\
\end{array}$ & $\begin{array}{l}7 \\
5\end{array}$ & $\begin{array}{l}8 \\
7\end{array}$ & $\begin{array}{l}2 \\
4\end{array}$ & $\begin{array}{l}7 \\
8\end{array}$ & $\begin{array}{l}5 \\
6\end{array}$ & $\begin{array}{l}8 \\
6 \\
\end{array}$ \\
\hline $\begin{array}{l}\text { Libr. B } \\
\text { Obs. }\end{array}$ & $\begin{array}{l}8 \\
8\end{array}$ & $\begin{array}{l}7 \\
8\end{array}$ & $\begin{array}{l}8 \\
4\end{array}$ & $\begin{array}{l}6 \\
6\end{array}$ & $\begin{array}{l}7 \\
8\end{array}$ & $\begin{array}{l}9 \\
8\end{array}$ & $\begin{array}{l}7 \\
6\end{array}$ & $\begin{array}{l}8 \\
6\end{array}$ & $\begin{array}{l}6 \\
6\end{array}$ & $\begin{array}{l}5 \\
4\end{array}$ \\
\hline $\begin{array}{l}\text { Libr. C } \\
\text { Obs. }\end{array}$ & $\begin{array}{l}6 \\
4 \\
\end{array}$ & $\begin{array}{l}7 \\
2 \\
\end{array}$ & $\begin{array}{l}6 \\
6 \\
\end{array}$ & $\begin{array}{l}7 \\
4 \\
\end{array}$ & $\begin{array}{l}6 \\
3 \\
\end{array}$ & $\begin{array}{l}1 \\
4\end{array}$ & $\begin{array}{l}5 \\
4 \\
\end{array}$ & $\begin{array}{l}3 \\
4 \\
\end{array}$ & $\begin{array}{l}7 \\
5\end{array}$ & $\begin{array}{l}5 \\
3 \\
\end{array}$ \\
\hline $\begin{array}{l}\text { Libr. D } \\
\text { Obs. }\end{array}$ & $\begin{array}{l}8 \\
4\end{array}$ & $\begin{array}{r}10 \\
7 \\
\end{array}$ & $\begin{array}{r}10 \\
7 \\
\end{array}$ & $\begin{array}{r}10 \\
5 \\
\end{array}$ & $\begin{array}{l}6 \\
3 \\
\end{array}$ & $\begin{array}{l}7 \\
3 \\
\end{array}$ & $\begin{array}{l}6 \\
6 \\
\end{array}$ & $\begin{array}{l}3 \\
5 \\
\end{array}$ & $\begin{array}{l}8 \\
6 \\
\end{array}$ & $\begin{array}{l}4 \\
5 \\
\end{array}$ \\
\hline $\begin{array}{l}\text { Libr. E } \\
\text { Obs. }\end{array}$ & $\begin{array}{l}3 \\
4\end{array}$ & $\begin{array}{l}4 \\
7\end{array}$ & $\begin{array}{l}5 \\
8\end{array}$ & $\begin{array}{l}5 \\
7\end{array}$ & $\begin{array}{l}5 \\
5\end{array}$ & $\begin{array}{l}5 \\
7\end{array}$ & $\begin{array}{l}3 \\
7\end{array}$ & $\begin{array}{l}5 \\
7\end{array}$ & $\begin{array}{l}3 \\
6\end{array}$ & $\begin{array}{l}3 \\
7\end{array}$ \\
\hline
\end{tabular}

"Each tabular number represents the rating, by a librarian or the observer, of either a 1-10 rating of energy/effort being expended or a 1-10 rating of enjoyment evidenced/felt during the observers' weekly visit. Where possible, the observer's ratings exclude conversations with librarians. 
joyment most closely matched the observer's were also the most likely to have made realistic beginnings in writing for publications. Thus, ratings of the intensity and enjoyment of particular jobs could be of value in analyzing how likely librarians are to publish.

\section{Do Librarians Have Less Time for Scholarly Writing?}

About 8 percent of the librarians did not comply with observer requests for weekly self-report sheets. The noncompliance rate for faculty was 14 percent. Figure 1 depicts the mean workweek of the librarians. The curves generally confirm contentions in the literature that librarians put in full workweeks on campus: not including vacations, the mean time worked was 40.2 hours per week. ${ }^{14}$

The figure also shows that librarians put in longer workweeks on campus than the faculty. The ten faculty members who completed self-reports spent much less time on campus than the librarians did.

At first glance, then, faculty members appear to have time for research and scholarship, while librarians do not.

\section{The Search for Sufficient Time}

Despite the initial appearance of available time, the faculty members consistently claimed that they were too busy for scholarly writing. In addition to their report of an overall mean of 23.5 hours per week on campus, all faculty (cf., only two librarians) indicated that some teachingrelated activity was done at home. These activities included grading papers and tests, preparing lectures and syllabi, and reading in preparation for lectures. If these unverified reports are given even partial credence, the workweeks of the faculty more closely approach those of librarians. Even if faculty exaggerate their workweeks, they seem to believe firmly that they do not have time for writing.

Reports about how faculty cope with new pressures for research and scholarship usually end with the confirmation of faculty claims of too little time amid already overloaded schedules. But the tracking procedure used in this study suggests the need for further examination.

\section{"Librarians and faculty members were frequently observed doing things that were spontaneously de- scribed by them as nonessential or in- efficient."}

Librarians and faculty members were frequently observed doing things that were spontaneously described by them as nonessential or inefficient. Faculty members might have regular visitors during office hours who chatted for 2 hours about current events or sports. Just as often, they sat reading newspapers or magazines, waiting for students, or engaging in other relatively unproductive activities. Librarians often spent time on similar activities, when more structured tasks such as desk assignments did not intervene.

Assessing the availąbility of time began with an examination of requirements for certain core activities. Figure 2 shows the mean time spent on desk assignments by eight of the same eleven librarians depicted in figure 1 . These self-reported weekly means included time at the reference desk, at a separately staffed information desk, or at a bibliographic instruction station other than the classroom (a creditearning library skills program requires students to consult with librarians and other staff). A comparison between the reference and consultation workweek of the librarians (figure 2) and the core workweek of faculty members shows a striking similarity. Both cores hover around 15 to 20 hours per week, for desk assignments on one hand and for lecture time plus office hours on the other.

Of course, both groups typically add other, generally obligatory assignments to their core workweek. Both groups attend committee meetings. Faculty members often work with students on individual projects. Librarians often work with individual students and faculty by doing online searching, and lecturing to classes. When these other essential activities are added to the reference and consultation activity, the resultant patterns of at least 25- to 28- 


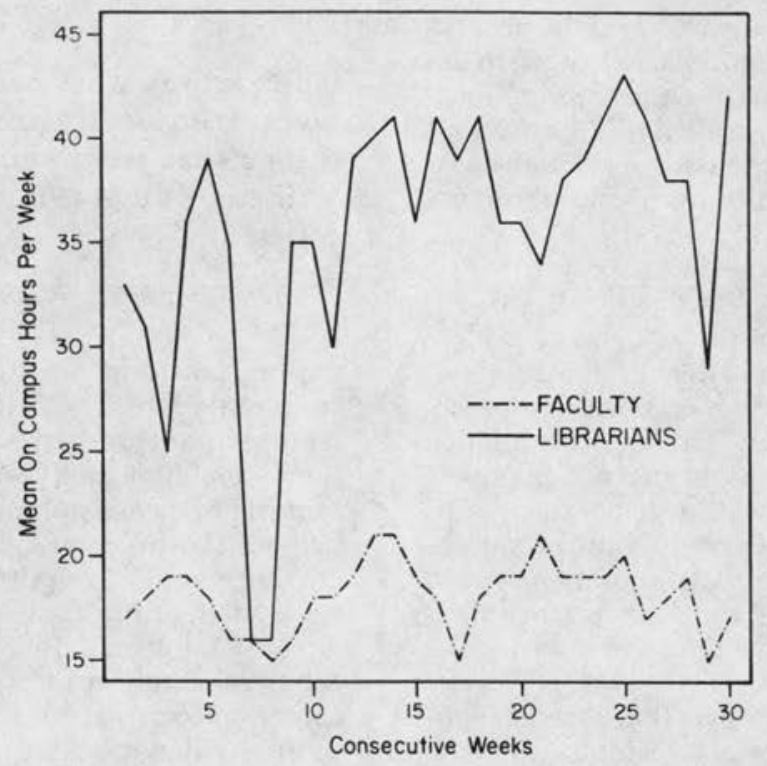

FIGURE 1

hour workweeks for these librarians resemble the on-campus workweeks of traditional faculty depicted in figure 1 . Even when librarians' additional assignments, such as collections development, were added, analysis of the tracking data produced a surprise. Both groups seemed to have discretionary time that could have been devoted to scholarship. When asked about this possibility, almost every participant gave the same answer: the occasional breaks in an otherwise busy schedule, were not sufficient for scholarship. Writing, they pointed out in almost complete agreement, requires large blocks of uninterrupted time. Thirty-minute blocks were too short.

One could accept these earnest arguments. These individuals were already doing a conscientious and competent job in the service sphere. Should more be expected? One response is that scholarly writing has become a required activity for both groups; a second is that scholarship could improve teaching effectiveness and could enhance the services librarians provide.

\section{Finding Time in Busy Schedules}

Faculty members who found time to write provided clues about how they did it. The most efficient and productive writers simply write during the brief openings in their service-oriented schedules. Equally important, they make writing a priority, and distractions such as phone calls are minimized.

\section{"The most efficient and productive writers simply write during the brief openings in their service-oriented schedules."}

These points were made to both groups at brief workshops held early in the project. Workshop participants were told about a study in which eight faculty members in another university who had written only in binges, i.e., large blocks of time, were enticed to write in brief (thirty to forty-five minute), daily sessions. ${ }^{16} \mathrm{~A}$ sixfold increase in the amount written was reported, and a substantial improvement occurred in the self-rated comfort with writing. 


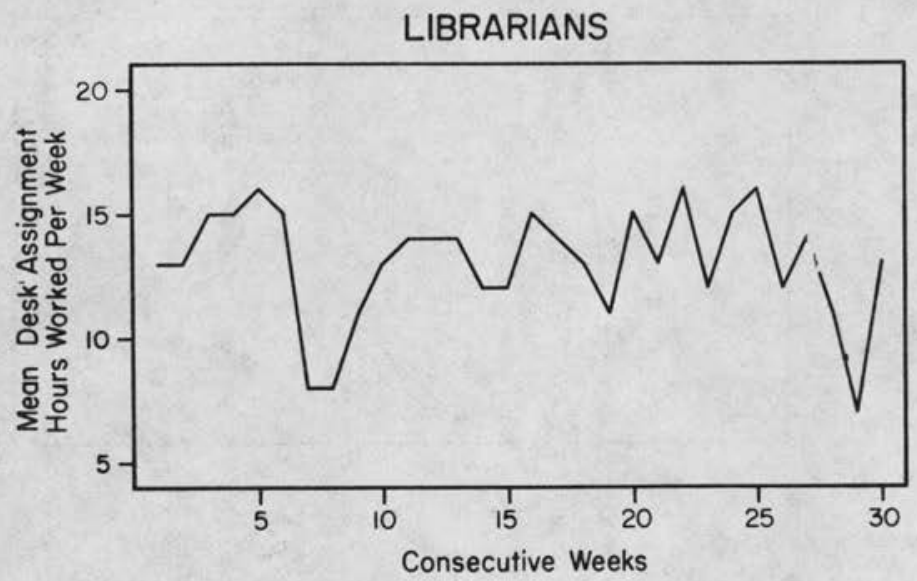

FIGURE 2

Short-Term Results: Did Librarians and Faculty Make Use of Available Time?

All twenty-four of the subjects in the present study listened cooperatively to suggestions about how to find the time to write, but few in either group pursued the idea seriously in the first seven months. Figure 3 depicts the result. Only one person from the faculty group began writing regularly. On the whole, neither group produced scholarship that was likely to meet the expectations of their campus administrators, that is, one article a year published in a refereed journal.

Moreover, neither group reported substantial writing at home. Three librarians indicated occasional-to-frequent writing off campus, two of them meeting expectations. Two of the faculty members wrote at home and were likely to publish at least one refereed article a year. This should be tempered by the fact that all five were merely continuing patterns that had been established before the study. Four of them stated strongly that scholarship was tantamount to personal indulgence; it had to be done on one's own time, not on campus where service to students or others is the consuming priority.

\section{Why Most Faculty Members and Librarians Don't Write}

Such concerns as fear of failure, nega- tive reviewers, and competition for limited space in journals may have inhibited some faculty from writing. ${ }^{17}$ These may also apply to librarians. But the fact remains that some librarians and faculty do publish. Why did participants in this study fail to alter their habits?

Momentum may be a significant factor. More than a semester may be needed to change long-standing habits of devoting workweeks almost exclusively to service for students and others in the academic community. A second reason may be that those unused to scholarship may feel unprepared and unqualified to write.

Faculty reasons for why they made little sustained effort at writing are cited below according to frequency:

1. Too busy to write

2. Service to students comes first

3. Good writing requires large blocks of time

4. Only original, significant thoughts merit production

5. The editorial process is cruel and unfair/fears of failure

6. An inherent aversion to writing

"scholarship was tantamount to personal indulgence..." 


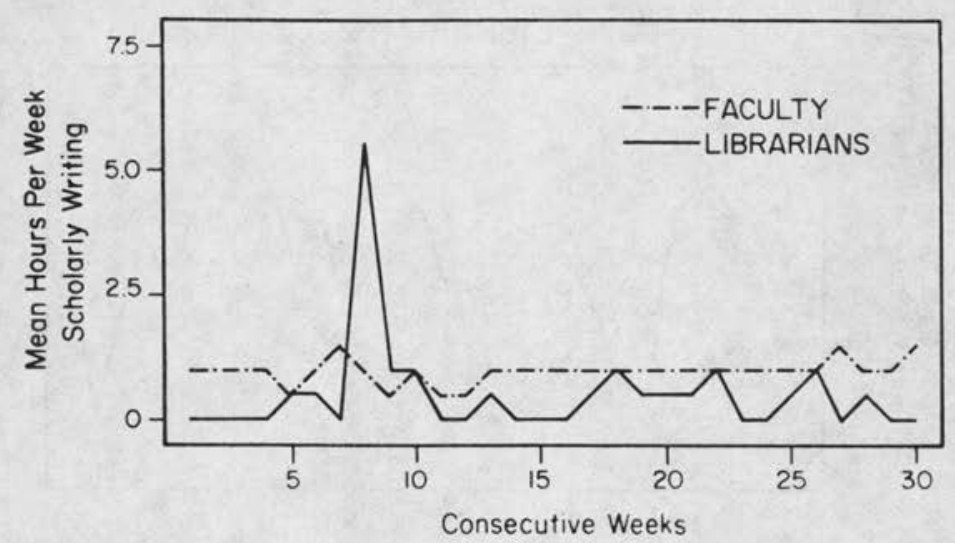

FIGURE 3

Librarians responded similarly when asked why they did not write, citing an additional factor never mentioned by faculty. Some believed that writing inevitably undermines the teamwork that is necessary to provide excellent library services.

Maladaptive beliefs about scholarly writing are not easily surrendered. Individuals in the study may have been stymied by lack of ideas and of cultural support; the traditional service-oriented culture of both groups provides little encouragement or continuing education for scholarly writing. Becoming a productive writer may mean more than merely finding time to write.

\section{CONCLUSION}

Overall, librarians and their faculty colleagues are very similar in their approaches to scholarly writing. The two groups showed similar patterns for the use of their discretionary time and for responding to the demand for scholarly writing. For both groups core activities and other requirements typically fill most but not all hours in the workweek. Time for writing was available, time for faculty members and time for librarians. Both groups used time in an inefficient or even unproductive way. Librarians and faculty members had seemingly busy schedules and placed a far greater priority on service than on scholarship. The two groups also showed a similar resistance to writing.

Given new insights about the practicality of writing during brief interludes in their service-oriented schedules, would the librarians and faculty members begin to cope with the demands for scholarship? The two groups responded similarly. Few made on-campus or off-campus writing even an occasional activity. Most in both groups remained convinced that they were too busy to write and that writing comes at the expense of good teaching or service.

The similarity between academic librarians and faculty members leads to several observations. The first is that librarians can better understand their own struggles with faculty status by looking at the struggle of traditional faculty. There is no obvious reason why librarians would not respond positively to development programs that offer more systematic direction and support than are currently provided to participants in this study. ${ }^{18}$

Secondly librarians are similar to their faculty colleagues: they have comparable attitudes about publishing and a commitment to excellence in service. Finally, the observer in this study, a traditional faculty member who has studied his colleagues for two decades, learned that librarians are as bright, intellectual, scholarly, and competent as their faculty counterparts. 


\section{REFERENCES}

1. Wendy Culotta and Kee DeBoer, "The Academic Librarian and Faculty Status in the 1980s," College \& Research Libraries 48:215-23 (May 1987); Barbara B. Moran, Academic Libraries: The Changing Centers of Colleges and Universities (Washington, D.C.: Assn. for the Study of Higher Education, 1984).

2. Fred Batt, "Faculty Status for Academic Librarians: Justified or Just a Farce?" in Issues in Academic Librarianship, ed. Peter Spyers-Duran and Thomas Mann (Westport, Conn.: Greenwood, 1985), p.115-28; Joyce Payne and Jane Y. Wagner, "Librarians, Publication, and Tenure," College \& Research Libraries 45:133-39 (Mar. 1984).

3. Russ Davidson, Connie Capers Thorson, and Diane Stine, "Faculty Status for Librarians: Querying the Troops," College \& Research Libraries 44:414-20 (Nov. 1983).

4. R. Eugene Rice, "Being Professional Academically," To Improve the Academy 5:5-13 (1984).

5. Jack H. Schuster and Howard R. Bowen, "The Faculty at Risk," Change 17:13-21 (Sept./Oct. 1985).

6. John A. Centra, "Research Productivity and Teaching Effectiveness," Research in Higher Education 18:379-89 (1983).

7. Stanley J. Michalak and Robert J. Friedrich, "Research Productivity and Teaching Effectiveness at a Small Liberal Arts College," Journal of Higher Education 52:578-97 (Nov./Dec. 1981).

8. Robert Boice, "Reexamination of Traditional Emphases in Faculty Development," Research in Higher Education 21:195-209 (1984).

9. Robert Boice and Karin Johnson, "Perceptions of Writing and Publication amongst Faculty at a Doctoral Degree Granting University," Research in Higher Education 21:33-43 (1984).

10. Chester E. Finn, "Trying Higher Education: An Eight Count Indictment," Change 16:29-51 (May/June 1984).

11. Robert Boice, "Is Released-Time an Effective Component of Faculty Development Programs?" Research in Higher Education 26:311-26 (1987).

12. Ibid.

13. Robert Boice, "Differences in Arranging Faculty Development through Deans and Chairs," Research in Higher Education 23:245-55 (1985).

14. Moran, Academic Libraries.

15. Boice, "Is Released-Time Effective Component?"

16. Robert Boice and Ferdinand Jones, "Why Academicians Don't Write," Journal of Higher Education 55:567-82 (Sept./Oct. 1984).

17. Robert Boice and Vivian P. Makosky, "Professional Writing: Increasing Productivity Decreasing Pain," Proceedings of Faculty Evaluation and Development; Lesson Learned 22:66-75 (Kansas State Univ., Center for Faculty Evaluation and Development, 1986).

18. Boice, "Is Released-Time Effective Component?" 